\title{
Isolation and Identification of Chitinase Producing Native Fungi From Saltpan of Puthalam, Kanyakumari District, Tamil Nadu, India
}

\author{
George Aldous Jenin ${ }^{1}$, Mariavincent Michael Babu², Manavalan Murugan ${ }^{3}$, Thanigaimalai Murugan ${ }^{3 *}$ \\ ${ }^{1}$ Department of Biochemistry, Lekshmipuram College of Arts and Science, Neyyoor- 629 252, Tamil Nadu, India. \\ ${ }^{2}$ Centre for Marine Science and Technology, Manonmaniam Sundaranar University, Rajakkamangalam - 629 502, Tamil Nadu, India. \\ ${ }^{3}$ Centre for Biological Science, Noorul Islam Centre for Higher Education, Kumaracoil- 629 180, Tamil Nadu, India.
}

\begin{tabular}{|c|c|}
\hline ARTICLE INFO & ABSTRACT \\
\hline Article history: & \multirow{6}{*}{$\begin{array}{l}\text { The objective of the present study is isolation and identification of native chitinolytic fungal strains from infected } \\
\text { Artemia collected for salt pan of Puthalam, Kanyakumari District, Tamil Nadu. A total of } 10 \text { fungi (J1 to J10) } \\
\text { were isolated from homogenized Artemia sample and screened for chitinase activity on chitin agar plates. In this } \\
\text { study, } 5 \text { fungi (J1, J3, J4, J5, \& J8) showed positive result of chitinase activity and } 2 \text { best strains (J1 \& J5) were } \\
\text { selected for further study. Fungi J1 and J5 were identified as Aspergillus niger and Aspergillus fumigatus } \\
\text { respectively. Greater quality of the enzyme production was achieved with the above strains and the molecular } \\
\text { weight of the chitinase was determined by SDS-PAGE it was found to be around } 23 \text { KDa. Finally, degradation } \\
\text { property of enzyme was assayed with chitin shell waste powder and observed that, degradation activity was } \\
\text { higher in shrimp shell powder followed by Prawn shell. The fungal strains such as A. niger and A. fumigatus have } \\
\text { been identified as good chitinase producers. }\end{array}$} \\
\hline Received on: $13 / 04 / 2016$ & \\
\hline Revised on: $04 / 05 / 2016$ & \\
\hline Accepted on: $27 / 05 / 2016$ & \\
\hline Available online: $21 / 06 / 2016$ & \\
\hline $\begin{array}{l}\text { Key words: } \\
\text { Chitinase, Aspergillus, } \\
\text { Artemia and Salt pan. }\end{array}$ & \\
\hline
\end{tabular}

\section{INTRODUCTION}

Microorganisms produce many secondary metabolites includes enzymes, pigments, antibiotics which could be of importance to mankind in many ways [1]. Microbial enzymes have several advantages over the enzymes resulting from plants or animals by high merit of their great variety of catalytic activities [2]. Bacteria and fungi are the source for several industrial enzymes includes DNase, lipase, alginase, proteases, chitinases and glutaminase [3, 4]. Chitinase is secondary metabolites produced by a number of naturally occurring microbes. In recent years, the demand for chitinase enzymes with new or attractive properties has augmented due to industrial application of chitin, chitosan and chitooligosaccharides [5]. Chitin is a $\beta 1-4$ linked homopolymer of N-acetylglucosamine, it is the second most abundant biodegradable polymer, can be found as a part of fungi, plants, crustaceans, insects, arthropods, and algae components [6]. Approximately $75 \%$ of the total weight of shellfish, such as shrimp, crabs and krill are considered

\footnotetext{
* Corresponding Author

Thanigaimalai Murugan, Centre for Biological Science, Noorul Islam Centre for Higher Education, Kumaracoil- 629 180, Tamil Nadu, India Email: muruganbt@gmail.com
}

as waste, and chitin comprises 20 to $58 \%$ of the dry weight of the said waste [7]. Chitinase play important role in the treatment of chitin waste. The chitin wastes especially derived from sea-foodprocessing units cause remarkable environmental problems worldwide and the production chitinolytic enzyme is an important element to the utilization of shellfish wastes [8]. Several microorganisms, including bacteria such as Serratia marcescens, Bacillus lichiniformis, Bacillus subtilis, Bacillus thuringiensis, and Vibrio alginolyticus [9-11] and many species of fungi such as Asergillus sp., Myrothecium anisopliae, Streptomyces sp., Trichoderma harzianum, Trichoderma viride, and Verticillium lecanii [12-17] have chitinase producing ability. The aim of the present study is isolation and identification of native chitinolytic fungal strains.

\section{MATERIALS AND METHODS}

\subsection{Collection of sample}

An infected Artemia (A.parthenogenetica) was collected from saltpan of Puthalam, Kanyakumari District, Tamil Nadu, India. The sample was collected in sterile glass container and immediately brought to the laboratory for further work. 


\subsection{Processing of sample}

The collected sample was rinsed with sterile distilled water for several times to remove soil and other debris and then filtered by muselin cloth filters in order to remove excess liquids. After, about $1 \mathrm{gm}$ of the sample was homogenized with $5 \mathrm{ml}$ of sterilized saline water using morter and pestle.

\subsection{Isolation of fungal strains}

The homogenized Artemia sample was used for isolation of fungi. An aliquot of $0.1 \mathrm{ml}$ of homogenized sample was spread evenly over the surface of Potato dextrose agar (PDA) and Sabouraud dextrose agar (SDA) medium using L-rod. Then, the plates were incubated at room temperature for 3 to 5 days. After incubation, the morphologically different fungal colonies were subcultured into PDA agar plates.

\subsection{Screening of chitinase activity}

The isolated fungal strains were screened for chitinase activity on chitin-agar medium. $1000 \mathrm{ml}$ of the medium consist of $\left(\mathrm{NH}_{4}\right)_{2} \mathrm{SO}_{4}(1 \mathrm{~g}), \mathrm{K}_{2} \mathrm{HPO}_{4}(1 \mathrm{~g}), \mathrm{KCl}(0.5 \mathrm{~g}), \mathrm{NaCl}(5 \mathrm{~g}), \mathrm{MgSO}_{4}$ $(0.5 \mathrm{~g}), \mathrm{FeSO}_{4}(0.01 \mathrm{~g})$, agar agar $(20 \mathrm{~g})$ and colloidal chitin $(5 \mathrm{~g})$. A portion of isolated fungus inoculated on chitin agar plates, incubated at room temperature for 6-8 days. The chitinase activity was observed by the halo zone of clearances around the fungal colonies, further it may be confirmed by adding Congo red dye solution.

\subsection{Characterization and identification of chitinolytic fungi}

The chitinase producing fungi were subjected to identification based on cultural and morphological characteristics. Growth colour, texture and pigments were observed macroscopically and structure of the fungi was observed by microscopically using lacto phenol cotton blue staining $[18,19]$.

\subsection{Production of chitinase}

Production of chitinase enzyme was carried out in $250 \mathrm{ml}$ of conical flask with $50 \mathrm{ml}$ of production medium, which consist of the following constituents $(\mathrm{g} / \mathrm{L})\left(\mathrm{NH}_{4}\right)_{2} \mathrm{SO}_{4}(1 \mathrm{~g}), \mathrm{K}_{2} \mathrm{HPO}_{4}(1 \mathrm{~g})$, $\mathrm{KCl}(0.5 \mathrm{~g}), \mathrm{NaCl}(5 \mathrm{~g}), \mathrm{MgSO}_{4}(0.5 \mathrm{~g}), \mathrm{FeSO}_{4}(0.01 \mathrm{~g})$, and colloidal chitin $(5 \mathrm{~g})$. The flasks were inoculated with $1 \mathrm{ml}$ of fungal suspension and then incubated at $30^{\circ} \mathrm{C}$ under shaking condition (160 rpm) for 7 days.

\subsection{Purification of enzyme}

The crude enzyme suspension was precipitated with $75 \%$ (w/v) of ammonium sulphate. The mixture was kept for overnight at $4^{\circ} \mathrm{C}$. The pellet was recovered by centrifugation and dissolved in $50 \mathrm{mM}$ phosphate buffer (pH 7.0). The suspension was dialyzed against distilled water for 24 hours and the solutions obtained after dialysis was loaded on Sephadex G-100 columns for further purification to standardize homogeneity levels. $100 \mathrm{mM}$ phosphate buffer was used as elution buffer and the fractions were collected at flow rate was $0.5 \mathrm{ml} / \mathrm{min}$.

\subsection{Estimation of chitinase activity and protein concentration}

Chitinase activity was determined spectrophotometrically by estimating the amount of free reducing groups formed after colloidal chitin hydrolysis. The reaction mixture consist of $1 \%$ colloidal chitin (suspended in $0.02 \mathrm{M}$ phosphate buffer $\mathrm{pH}$ 7) 0.5 $\mathrm{ml}$ of enzyme solution. The mixture was incubated at $30^{\circ} \mathrm{C}$ for 1 hour. The product was measured in $1 \mathrm{ml}$ of filtrate by dinitrosalicylic acid (DNS) method using N-acetylglucosamine as standard [9]. Total protein content of the enzyme was estimated by the method of Lowry et al. [20] using bovine serum albumin (BSA) as standard.

\subsection{Molecular weight determination}

Sodium dodecyl sulphate polyacrylamide gel electrophoresis (SDS-PAGE) was performed on $12 \%$ polyacrylamide gel, by the method of Laemmli [21]. The sample was treated with sample buffer and boiled at $100^{\circ} \mathrm{C}$ for $3 \mathrm{~min}$ before loading. A voltage of $100 \mathrm{~V}$ was applied and the gel was left running for 45 minutes to achieve sufficient migration. Proteins were visualized by staining the gel with Coomassie blue G-250 and the molecular weight of the enzyme was determined by comparing with the bands of standard marker protein.

\subsection{Study of degradation activity}

Degradation activity of chitinase was performed with various chitin shell waste viz., Shrimp shell, Prawn shell, Crab shell and Squid shell. Potato dextrose agar plate was prepared with $2 \%$ chitin waste powers. The medium was autoclaved at $121^{\circ} \mathrm{C}$ for 20 minutes and poured into sterile Petri dishes. After solidification, well (about $6 \mathrm{~mm}$ in diameter) was made on the surface of agar plate using well cutter. After, about $50 \mu \mathrm{l}$ of crude enzyme suspension was poured into the well in an aseptic manner. Then, the plates were incubated at $30^{\circ} \mathrm{C}$ for about $10-15$ days and/ or observed periodically to ensure the zone formation around the well.

\section{RESULTS}

\subsection{Isolation of fungal strains}

In this present study, a total of 10 different fungal colonies were recovered from the homogenized sample of infected Artemia. All the colonies were individually subcultured on PDA agar plates and screening of chitinase activity was performed.

\subsection{Screening of chitinase activity}

The presence of clear halo around the colonies indicates the chitinase activity of the fungus. In this investigation, five fungal strains (J1, J3, J4, J5, \& J8) showed positive result for chitinase production. Among five, 2 best strains such as J1 \& J5 were selected for further study.

\subsection{Characterization and identification of chitinolytic fungi}

The best two strains were identified by studying cultural and morphological characteristics (Table 1). Based on the 
characters studied, the strain J1 and J5 were identified as Aspergillus niger and Aspergillus fumigatus respectively.

Table 1: Cultural and morphological characters of fungi.

\begin{tabular}{clcc}
\hline SL. & Characteristics & A. niger & A. fumigatus \\
No. & Colony color & Black & Pale green \\
\hline 1 & Colony appearance & Spread spores & Spread spores \\
2 & Smooth & Smooth \\
3 & Colony texture & Smooth colony & Smooth colony \\
4 & Surface of the colony & Present & Present \\
5 & Conidial head & - & - \\
6 & Sporangium & - & - \\
7 & Stipe & - & - \\
8 & Phialides & - & - \\
9 & Conidia shape & Ovaid & Ovaid \\
10 & Vesicles shape & Biseriate vesicles & uniseriate \\
11 & Vesicles arrangement & vesicles \\
& & Entirely covering & Upper 2/3 \\
12 & Appearance of Metula & medulla & covering medulla \\
13 & Medulla shape & Oval shape & Glubose shape \\
14 & Rhizoids & - & - \\
\hline
\end{tabular}

\subsection{Production of chitinase}

The chitinase was produced by using best two strains. After 7 days of incubation, the flask containing production medium was centrifuged and the supernatant containing crude enzyme was used for further studies.

\subsection{Estimation of chitinase activity and protein concentration}

The enzyme activity was estimated calorimetrically and the values calculated using standard values of standard $\mathrm{N}$ acetyl glucosamine. Total protein content was calculated based the values of standard bovine serum albumin. The enzyme activity and protein concentration of the chitinase enzyme produced by A.niger and A.fumigatus mentioned in table 2.

Table 2: Total enzyme activity and protein concentration of chitinase.

\begin{tabular}{cccc}
\hline $\begin{array}{c}\text { SL. } \\
\text { No. }\end{array}$ & Strain Name & $\begin{array}{c}\text { Total activity } \\
(\boldsymbol{\mu g} \text { moles/ml/min) }\end{array}$ & $\begin{array}{c}\text { Total protein } \\
(\mathbf{m g} / \mathbf{m l})\end{array}$ \\
\hline 1 & A.niger & 0.612 & 21 \\
2 & A.fumigatus & 0.575 & 18 \\
\hline
\end{tabular}

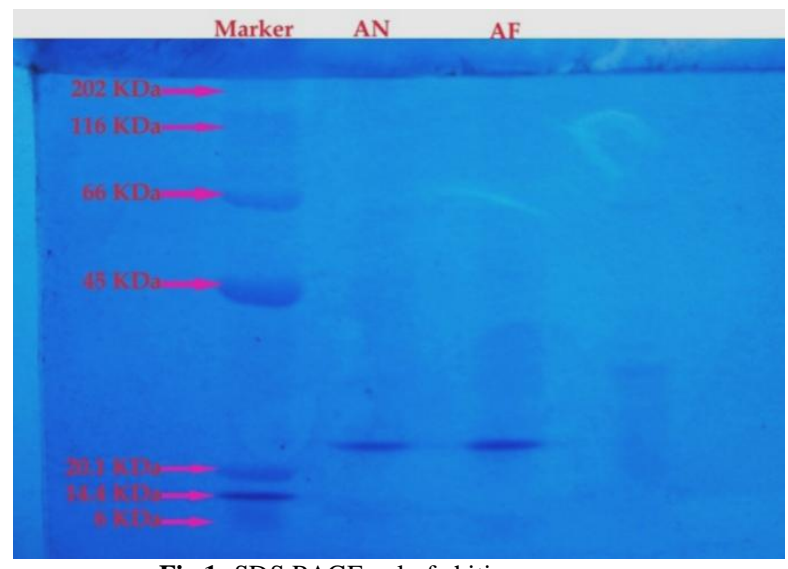

Fig 1: SDS PAGE gel of chitinase enzyme

\subsection{Molecular weight determination}

The protein band of chitinas enzyme was observed and it was compared with the bands of standard marker proteins. In this study, the molecular weight of the chitinases from A.niger and A.fumigatus were found to be around $23 \mathrm{KDa}$ (Fig. 1).

\subsection{Study of degradation activity}

It was observed that, the chitinase produced by Aspergillus fumigatus have the ability to degrade chitinase waste. The degradation activity was higher in shrimp shell powder followed by Prawn shell. In crab shell and Squid shells, the enzyme showed moderate degradation (Figure 2).

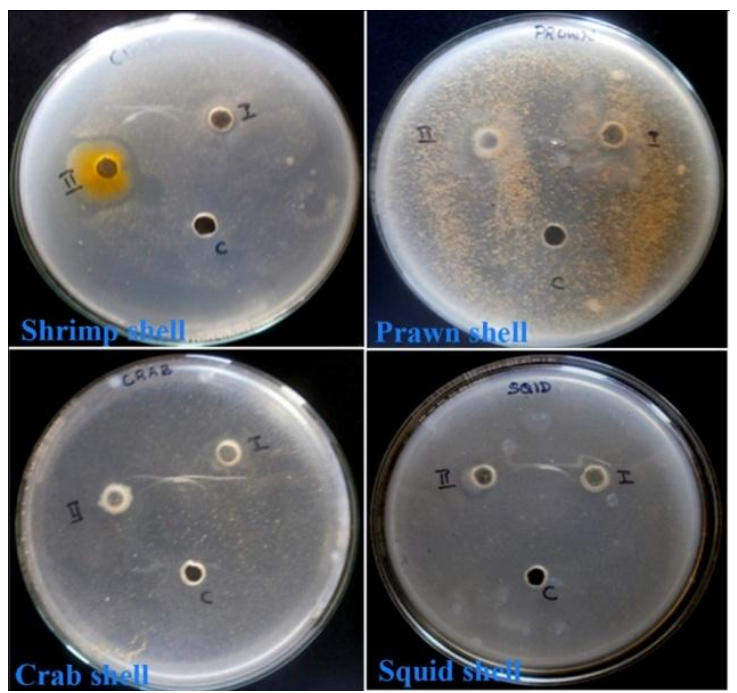

Fig 2: Degradation activity of chitinase

\section{DISCUSSION}

Chitinases are widely distributed in microorganisms, the filamentous fungi including Trichoderma, Oenicillium, Penicillium, Lecanicillium, Neurospora, Mucor, Beauveria, Lycoperdon, Aspergillus, Myrothecium, Conidiobolus, Metharhizium, Stachybotrys and Agaricus [22-24].

In this present study, the two fungal species belonging to the genus Aspergillus such as A.niger and A.fumigatus were found to be good chtinase producers. In those two strains, the first one i.e A.niger showed more enzyme than A. fumigatus. Sharaf [25] reported that the genus Aspergillus is comprised of A. flavus, A. foetidus, A. niger and A. ungius. A. flavus and A. alternata which were developed on the plates containing colloidal, treated and crude chitin, exhibits a strong chitinolytic activity. In this present study, colloidal chitin prepared from chitin shell powder was used as substrate and more quantity of chitinase enzyme was achieved. Purification of chitinase enzyme produced by Aspergillus species was done by chromatography. The molecular mass of the enzymes were studied by SDS-PAGE using $10 \%$ acrylamide gel and coomassive brilliant blue R250 as staining reagent. These purified chitinases were probably new since the molecular mass was found to be $23 \mathrm{KDa}$, is different from the previously published values of $33,43.5$, and $45 \mathrm{kDa}[26,27]$.

Chitin is one of the most abundant polysaccharides on the earth. A lot of chitineous substances are found in the shells of shrimp, crabs, lobsters [28]. However, these substances are 
discarded as wastes and its degradation is of great importance as it can supply to both carbon and nitrogen cycles in the biosphere [29]. The ability of bacteria, fungi, and actinomycetes to produce chitinolytic enzymes is common in nature. The great majority of these organisms are able to effectively break down chitin and use it as a source of carbon and energy and also to produce chitinases [30]. In this present study, degradation activity of chitinase enzyme was studied against various chitins containing substances. The degradation activity was higher in shrimp shell power followed by Prown shell. Also, the degradation occurred after 8 days of incubation. This result was supported by the studies of Rattanakit et al. [31] and Hoang et al. [32].

\section{CONCLUSION}

The fungal strains such as Aspergillus niger and Aspergillus fumigatus have been identified as good chitinase producers isolated from infected Artemia collected from the saltpan of Puthalam. It was confirmed that, the purified enzyme was able to degrade chitin waste substances. In future interest will be taken to scale up the production of chitinase by using various agro residues in solid state fermentation.

\section{REFERENCES}

1. Giri AV, Anandkumar N, Muthukumaran G, Pennathur G. A novel medium for the enhanced cell growth and production of prodigiosin from Serratia marcescens isolated from soil. BMC Microbiol. 2004; 4:11-17.

2. Cheetham PSJ. In Handbook of Enzyme Biotechnology. $2^{\text {nd }}$ ed. England Ellis Horwood Ltd; 1985.

3. Renu S, Chandrasekaran M. Extracellular L-glutaminase production by marine bacteria. Biotechnology Letters. 1992; 14:471-474.

4. Prabhu NG, Chandrasekaran M. L-Glutaminase marine Vibrio costicola under solid- state fermentation using different substrates. Journal of Marine Biotechnology. 1996; 4:176-179.

5. Sudhakar P, Nagarajan P. Production of chitinase by solid state fermentation from rice bran. International Journal of Environmental Science and Development. 2010; 1(5): 435-440.

6. Gohel, Anil Singh, Vimal M, Ashwini P, Chhatpar HS. Bioprospecting and antifungal potential of chitinolytic microorganisms. African Journal of Biotechnology. 2006; 5 (2):54-72.

7. Wang SL, Chang WT. Purification and characterization of two bifunctional chitinases/lysozymes extracellularly produced by Pseudomonas aeruginosa K-187 in a shrimp and crab shell powder medium. Applied and Environmental Microbiology. 1997; 63:380-386.

8. Berahim Z. Production of Chitinase by a locally isolated fungus. FBSB. 2007; 22.

9. Joshi S, Kozlovski M, Richens S, Comberbech DM. Chitinase and chitobiase production during fermentation of genetically improved Serriatia liquifaciens. Enzyme and Microbial Technology. 1989; 11:289-296.

10. Wang SL, Lin TY, Yen YH, Liao HF, Chen YJ. Bioconversion of shellfish chitin wastes for the production of Bacillus subtilis W118 chitinase. Carbohydrate Research. 2006; 341(15):2507-2515.

11. Merina PD, Rebecca LJ, Sharmila SA, Banerji A, Kumar D. Identification and optimization of cultural conditions for chitinase production by Bacillus amyloliquefaciens SM3. Journal of Chemical and Pharmaceutical Research. 2012; 4(11):4816-21.

12. De Siqueira PA, Barreto CC, Schrank A, Ulhoa CJ, Henning Vainstein M. Purification and characterization of extra cellular chitinase from the entomopathogen Metarhizium anisopliae. Canadian Journal of Microbiology. 1997; 43:322-327.

13. Mathivanan N, Kabilan V, Murugesan K. Purification, characterization and antifungal activity of chitinase from Fusarium chlamydosporum, a mycoparasite to groundnut rust, Puccinia arachids. Canadian Journal of Microbiology. 1998; 44(7):646-651.

14. Liu BL, Kao PM, Tzeng YM, Feng KC. Production of chitinase from Verticillium lecanii F091 using submerged fermentation. Enzyme and Microbial Technology. 2003; 33:410-415.

15. Nampoothiri KM, Baiju TV, Sandhya C, Sabu A, Szakacs G, Pandey A. Process optimization for antifungal chitinase production by Trichoderma harzianum. Process Biochemistry. 2004; 39:1583.

16. Gunalan G, Sadhana D, Rupa Ramya P. Production, optimization of chitinase using Aspergillus flavus and its biocontrol against phytopathogenic fungi. Journal of Pharmacy Research. 2012; $5(6): 31-51$.

17. Sowmya B, Gomathi D, Kalaiselve M, Ravikumar G, Arulraj C, Uma C. Production and purification of chitinase by Streotomyces sp. from soil. Journal of Advanced Scientific Research. 2012; 3(3):25-29.

18. Machouart M, Larche J, Burton K, Collomb J, Maurer P, Cintrat A et al.. Genetic identification of the Main Opportunistic Mucorales by PCR-Restriction Fragment Length Polymorphism. Journal of Clinical Microbiology. 2006; 44(3):805-810.

19. Diba K, Kordbacheh P, Mirhendi SH, S Rezaie, M Mahmoudi. Identification of Aspergillus species using morphological characteristics. Pakistan Journal of Medical Sciences. 2007; 23(6):867-872.

20. Lowry OH, Rosebrough NJ, Farr AL, Randall RJ. Protein measurement with the Folin-Phenol reagents. Journal of Biological Chemistry. 1951; 193:265-275.

21. Laemmli UK. Cleavage of structural proteins during the assembly of the head of bacteriophage T4. Nature (London) 1970; 277:680-685.

22. Matsumoto KS. Fungal chitinases. Advances in agricultural and food. Biotechnology. 2006; 6:289-304.

23. Duo-Chuan L. Review of fungal chitinases. Mycopathologia. 2006; 161 (6):345-360.

24. Hartl L, Zach S, Seidl-Seiboth V. Fungal chitinases: Diversity, mechanistic properties and biotechnological potential. Applied Microbiology and Biotechnology. 2012; 93 (2):533.

25. Sharaf EF. A Potent Chitinolytic Activity of Alternaria alternata isolated from Egyptian Black Sand. Polish Journal of Microbiology. 2005; 54(2):145-151.

26. Leger RJ, Cooper RM, Charnley AK. Characterization of chitinase and chitobiase produced by the entomopathogenic fungus Metarhizium anisopliae. Journal of Invertebrate Pathology. 1991; 58:415-426.

27. Leger RJ, Joshi L, Bidochka MJ, Roberts DW. Construction of an improved mycoinsecticide overexpressing a toxic protease. Proceedings of the National Academy of Sciences of the United States of America. 1996; 93:6349-6354.

28. Nopakarn $\mathrm{P}$, Abhinya $\mathrm{P}$, Yano S, Marunu W, Takashi T. Utilization of shrimp shellfish waste as a substrate for solid-state cultivation of Aspergillus sp. S1-13. Journal of Bioscience and Bioengineering. 2002; 93:550-556.

29. Reguera G, Leschine SB. Biochemical and genetic characterization of $\mathrm{Chi} \mathrm{A}$, the major enzyme component for the 
solubilization of chitin by Cellulomonas uda. Archives of Microbiology. 2003; 18:434-443.

30. Shubakov AA, Kucheryavykh PS. Chitynolytic activity of filamentous fungi. Biochemistry and Microbiology. 2004; 5:445.

31. Rattanakit N, Yano SH, Plikomol A, Wakayama M, Tachiki T. Purification of Aspergillus sp. S1-13 chitinases and their role in saccharification of chitin in mash of solid-state culture with shellfish waste. Journal of Bioscience and Bioengineering. 2007; 103(6):535-541.

32. Hoang KC, Lai TH, Lin CS, Chen YT, Liau CY. The chitinolytic activities of Streptomyces sp. TH-11. International Journal of Molecular Sciences. 2011; 12:56-65.

\section{How to cite this article:}

Jenin GA, Babu MM, Murugan M, Murugan T. Isolation and Identification of Chitinase Producing Native Fungi From Saltpan of Puthalam, Kanyakumari District, Tamil Nadu, India. J App Biol Biotech. 2016; 4 (03): 001-005. DOI: 10.7324/JABB.2016.40301 